\title{
Genotype by environment interaction for production, somatic cell score, workability, and conformation traits in Dutch Holstein- Friesian cows between farms with or without grazing
}

\author{
M. van der Laak, ${ }^{*}$ M. L. van Pelt, $†$ G. de Jong, $†$ and H. A. Mulder*1 \\ *Animal Breeding and Genomics Centre, Wageningen University, PO Box 338, 6700 AH Wageningen, the Netherlands \\ †CRV BV, Animal Evaluation Unit, PO Box 454, 6800 AL Arnhem, the Netherlands
}

\begin{abstract}
In this study, genotype by environment interaction was investigated for production traits, somatic cell score (SCS), workability traits, and conformation traits for Holstein-Friesian cows producing on farms with or without grazing in the Netherlands. Additionally, heritabilities and repeatabilities were estimated in both farm systems. Data were available for 1,019 Dutch farms, and farm type was known for those farms, 142 farms without grazing and 877 farms with grazing. The data set consisted of 428,600 test-day records for production from 49,412 cows, and from this data set a subset for SCS was created, consisting of 374,734 test-day records from 45,955 cows. For workability and conformation traits, the data set consisted of 30,180 cows. Bivariate mixed models with multiple fixed effects and random sire and random permanent environment effects were applied. The majority of sires had daughters in both farm types. The heritabilities for milk yield (0.27), fat yield (0.19), and protein yield (0.20) were higher in farms with grazing than in farms without grazing with heritabilities of 0.24 for milk yield, 0.18 for fat yield, and 0.18 for protein yield. Repeatability was lower in the grazing farms for milk yield, fat yield, and protein yield, probably because of alternating quality of dry matter intake during grazing. Genetic correlations between grazing and no grazing were 0.99, 0.98, 0.97, and 1.00 for milk yield, fat yield, protein yield, and SCS, respectively. Genetic correlations for workability traits and conformation traits between grazing and no grazing varied between 0.93 and 1.00. For all traits, genetic correlations were close to unity, indicating no genotype by environment interaction between farms with or without grazing for production traits, SCS, workability traits,
\end{abstract}

Received October 23, 2015.

Accepted February 11, 2016.

${ }^{1}$ Corresponding author: han.mulder@wur.nl and conformation traits in Dutch Holstein-Friesians. Therefore, the same sires can be used for farms with grazing and without grazing.

Key words: genotype by environment interaction, grazing, milk production, conformation

\section{INTRODUCTION}

The percentage of dairy cows kept on Dutch farms with year-round confinement increased from $10 \%$ in 2000 to $30 \%$ in 2013 (CBS, 2014). In the Netherlands, milk yield is higher in farms without grazing compared with farms with the traditional full grazing system (Reijs et al., 2013). Farms without grazing also showed higher BCS and higher BW in the United States (Washburn et al., 2002), and an increase in lameness and frequency of knee and hock swellings in Great Britain (Haskell et al., 2006). Better locomotion scores, straighter rear leg side view, steeper foot angle, and better legs and feet were observed on farms with grazing compared with farms without grazing in Great Britain (Onyiro and Brotherstone, 2008).

The question arises whether a genotype by environment interaction $(\mathbf{G} \times \mathbf{E})$ occurs between the 2 environments. The $\mathrm{G} \times \mathrm{E}$ is a phenomenon where the performance of different genotypes is not equally affected by the different environments (Falconer, 1989). As a result, genotypes that are performing well in one environment might be less successful in another environment. If $\mathrm{G} \times \mathrm{E}$ occurs, it can result in (1) a scaling effect, where the differences between sires in different environments are unequal but the ranking of sires is the same, or (2) reranking, a change in the ranking of sires across environments. With reranking, the genetic basis for the trait is different for each environment (Lynch and Walsh, 1998). In current breeding value estimation, the heterogeneity of variances is corrected for (Meuwissen et al., 1996), but possible reranking of sires in different environments is not taken into account (Calus et al., 2002). If sires with daughters in one environment are genetically evaluated and $\mathrm{G} \times \mathrm{E}$ occurs, the results 
might not be adequate predictors for offspring in other environments, thereby reducing the efficiency of genetic improvement programs (Boettcher et al., 2003; Mulder and Bijma, 2005; Mulder et al., 2006; Hammami et al., 2009). To avoid this problem, it would be better that selection of sires is performed in the environments in which daughters are expected to perform (Falconer, 1952).

Numerous studies investigated the possible existence of $\mathrm{G} \times \mathrm{E}$ in dairy cattle. The $\mathrm{G} \times \mathrm{E}$ was observed between climatic environments in the United States and Mexico (Cienfuegos-Rivas et al., 1999). Mulder et al. (2004) observed small reranking between farms with automatic and farms with conventional milking systems. Boettcher et al. (2003) and Kearney et al. (2004a,b) studied $\mathrm{G} \times \mathrm{E}$ between farms with grazing and no grazing in Canada and the United States, respectively, and genetic correlations ranged between 0.88 and 0.96 for production traits, and between 0.90 to 0.97 for conformation traits. In most $\mathrm{G} \times \mathrm{E}$ studies, reranking of sires did sometimes occur for a particular trait, but the differences between environments were not so large that separate genetic evaluations for each environment were advised (Boettcher et al., 2003; Mulder et al., 2004; Kearney et al., 2004a,b). In the Netherlands, it is unknown whether $\mathrm{G} \times \mathrm{E}$ exists between farms with grazing and no grazing.

The aim of this study was, therefore, to investigate the existence of $\mathrm{G} \times \mathrm{E}$ for milk yield, fat yield, protein yield, SCS, workability traits, and conformation traits between Holstein-Friesian cows producing in farms with or without grazing in the Netherlands.

\section{MATERIALS AND METHODS}

\section{Data}

Records of Dutch Holstein-Friesian cows were provided by CRV (Arnhem, the Netherlands). Farmers provided the grazing status to the database of CRV voluntarily. Selection of herds was done by CRV by selecting herds with a known grazing status (grazing or no grazing) for dairy cows in the years 2010, 2011, and 2012. Only herds that did not change their grazing system within these years and where at least $98 \%$ of the cows were Holstein Friesian were selected. The initial data set contained information from 1,019 herds, 142 herds without grazing and 877 herds with grazing. At farms with grazing, cows were grazing on average 10.9 $\mathrm{h} / \mathrm{d}$ and $161.1 \mathrm{~d} / \mathrm{yr}$.

Data sets for (1) production traits, (2) SCS, and (3) workability traits and conformation traits were created. The data sets were edited to conform to the standards used by CRV for breeding value estimation (CRV, 2013, 2014). Data editing was done using $\mathrm{R}$ software (R Core Team, 2014). All cows in the data sets were at least $7 / 8$ Holstein-Friesian and herd-book registered. Data set 1 contained 2,032,064 test-day records from 133,127 cows and contained information about first parity test-day milk samples from 5 to 335 d in milk. For every record, information about birth date, calving date, milk yield, protein yield, and fat yield was provided. From cows moving to a different herd, only records from the first herd were left in the data set. At least 5 daughters per sire, 5 cows per herd test date and 5 records per cow were required in the data set, resulting in 428,600 testday records from 49,412 cows. In data set 1, 773 sires had daughters in both farm types. Cows in data set 2 were selected in the same way as cows were in data set 1. However, the number of records was reduced because SCC was not measured at every test-day. The SCC is not normally distributed; therefore, SCC was transformed into SCS and was calculated by SCS $=100 \times$ $\left[\log _{2}(\mathrm{SCC})\right]$, which was slightly different from the equation used by CRV for breeding value estimation (CRV, 2014). The same edits were applied as in data set 1 . After editing, data set 2 contained 374,734 records from 45,955 cows. In data set 2, 729 sires had daughters in both farm types. Data set 3 contained 75,188 records from cows that were scored for 23 conformation traits and 2 workability traits (milking speed and temperament during milking) by a classifier on a certain date. Only records that were scored in 2010, 2011, or 2012 were kept in the data set. At least 5 cows per classification date per farm, 5 cows per combined variable of classifier and half year period of classification date and classification standard (Black-and-White and Red-andWhite), 5 cows per age class (18 mo classes: $<25$ mo, 25-40 mo, a separate class for each month, >40 mo), and 5 cows per lactation class (13 classes: each for 1 month of lactation and with the thirteenth category for 13 and more months of lactation) were required, remaining 28,694 cows in data set 3 . In data set 3,512 sires had daughters in both farm types. Details about the data sets are in Table 1.

The pedigree file contained pedigree information for all the cows in the data sets. The pedigree was trimmed with the "pedigree" package in R (Coster, 2012), and included the sire of the cow, the parents of the sire, and the grandparents of the sire.

\section{Statistical Analysis}

As was suggested by Falconer (1952), the same trait measured in farms with or without grazing was treated as 2 separate traits. The genetic correlation $r_{g}$ between 
environments is a measure of $\mathrm{G} \times \mathrm{E}$. The bivariate model was formulated in matrix notation as

$\left[\begin{array}{l}\mathbf{y}_{\mathbf{n}} \\ \mathbf{y}_{\mathrm{g}}\end{array}\right]=\left[\begin{array}{cc}\mathbf{X}_{\mathrm{n}} & \mathbf{0} \\ \mathbf{0} & \mathbf{X}_{\mathrm{g}}\end{array}\right]\left[\begin{array}{c}\mathbf{b}_{\mathrm{n}} \\ \mathbf{b}_{\mathrm{g}}\end{array}\right]+\left[\begin{array}{cc}\mathbf{z}_{\mathrm{n}} & \mathbf{0} \\ \mathbf{0} & \mathbf{Z}_{\mathrm{g}}\end{array}\right]\left[\begin{array}{c}\mathbf{s}_{\mathbf{n}} \\ \mathbf{s}_{\mathrm{g}}\end{array}\right]+\left[\begin{array}{cc}\mathbf{W}_{\mathrm{n}} & \mathbf{0} \\ \mathbf{0} & \mathbf{W}_{\mathrm{g}}\end{array}\right]\left[\begin{array}{c}\mathbf{p}_{\mathrm{n}} \\ \mathbf{p}_{\mathrm{g}}\end{array}\right]+\left[\begin{array}{l}\mathbf{e}_{\mathrm{n}} \\ \mathbf{e}_{\mathrm{g}}\end{array}\right]$,

where $\mathbf{y}_{\mathbf{i}}$ is the vector with test-day milk, protein and fat yield, SCS, workability, and conformation traits for environment $\mathrm{i}$ (subscript $\mathrm{n}$ is no grazing; subscript $\mathrm{g}$ is grazing); $\mathbf{b}_{\mathbf{i}}$ is the vector with all the fixed effects, $\mathbf{s}_{\mathbf{i}}$ is the vector with random sire effects for environment i, $\mathbf{p}_{\mathbf{i}}$ is the vector with random permanent environmental effect for production traits and SCS in environment $i$; and $\mathbf{e}_{\mathbf{i}}$ is the vector with random residual effect for environment i. $\mathbf{X}_{\mathbf{i}}, \mathbf{Z}_{\mathbf{i}}$, and $\mathbf{W}_{\mathbf{i}}$ are incidence matrices for the fixed effects, random sire effects, and random permanent environmental effect, respectively. In this study, we used a sire model because the information to estimate $\mathrm{G} \times \mathrm{E}$ was mainly through daughters of sires performing in the 2 environments, and sire models required less computing time and memory than animal models.

Fixed effects for production traits and SCS were herd test date, the Wilmink lactation curve (DIM and DIM2), where DIM is the numbers of days in milk and DIM2 was calculated by $\mathrm{e}^{-0.05 \times \mathrm{DIM}}$ (Wilmink, 1987), and the interaction between year of calving, age at first calving, and season of calving (year $\times$ age $\times$ season). The permanent environmental effect consisted of permanent environmental effect and the remaining genetic effects (dam genetic and Mendelian sampling effect) and was included in the model because of the repeated test-day observations on cows. Fixed effects for workability traits and conformation traits were classification date farm, classifier, and half-year period of classification date and classification standard, age of the cow in months at classifying, and lactation stage. Note that random permanent environmental effects were not fitted for workability and conformation traits because cows had only single records.
Sire effects, permanent environmental effect, and residual effects were assumed to follow a normal distribution with mean and variance:

$$
\begin{gathered}
{\left[\begin{array}{l}
\mathbf{s} \\
\mathbf{p} \\
\mathbf{e}
\end{array}\right] \mathbf{N}\left(\left[\begin{array}{l}
0 \\
0 \\
0
\end{array}\right],\left[\begin{array}{ccc}
\mathbf{G} & 0 & 0 \\
0 & \mathbf{P} & 0 \\
0 & 0 & \mathbf{R}
\end{array}\right]\right),} \\
\operatorname{var}[\mathbf{s}]=\mathbf{G}=\mathbf{C} \otimes \mathbf{A} \text { with } \mathbf{C}=\left[\begin{array}{cc}
\sigma_{s, n}^{2} & \sigma_{s, n g} \\
\sigma_{s, g} & \sigma_{s, g}^{2}
\end{array}\right], \\
\operatorname{var}[\mathbf{p}]=\mathbf{P}=\mathbf{I}_{\mathbf{p}} \otimes \mathbf{P} \text { with } \mathbf{P}=\left[\begin{array}{cc}
\sigma_{p e, n}^{2} & 0 \\
0 & \sigma_{p e, g}^{2}
\end{array}\right], \\
\operatorname{var}[\mathbf{e}]=\mathbf{R}=\mathbf{I}_{\mathbf{q}} \otimes \mathbf{E} \text { with } \mathbf{E}=\left[\begin{array}{cc}
\sigma_{e, n}^{2} & 0 \\
0 & \sigma_{e, g}^{2}
\end{array}\right],
\end{gathered}
$$

where $\mathbf{A}$ is the relationship matrix of the sires; $\sigma_{s, i}^{2}$ is the sire variance of environment $\mathrm{i} ; \sigma_{s, n g}$ is the sire covariance between environment $\mathrm{n}$ and $\mathrm{g} ; \mathbf{I}_{\mathrm{p}}$ is the identity matrix of $\mathrm{p} \times \mathrm{p}$ where $\mathrm{p}$ is the number of cows; $\sigma_{p e, i}^{2}$ is the permanent environmental variance of environment $\mathrm{i}$; $\mathbf{I}_{\mathbf{q}}$ is the identity matrix of $\mathrm{q} \times \mathrm{q}$ where $\mathrm{q}$ is the number of records; $\sigma_{e, i}^{2}$ is the residual variance of environment i; and $\mathbf{C}, \mathbf{P}$, and $\mathbf{E}$ are the variance-covariance matrices for the sire, permanent environmental, and residual variance, respectively. The permanent environmental effects were estimated with a diagonal matrix because the effects were uncorrelated between farms. No cows had records in both the grazing (g) and no grazing (n) environment.

\section{Genetic Parameters}

The analyses were performed with ASREML software (Gilmour et al., 2009). After estimating variance

Table 1. Number of records, cows, herd-test-day (HTD), herds, and sires from farms with and without grazing for production traits, SCS, workability and conformation traits

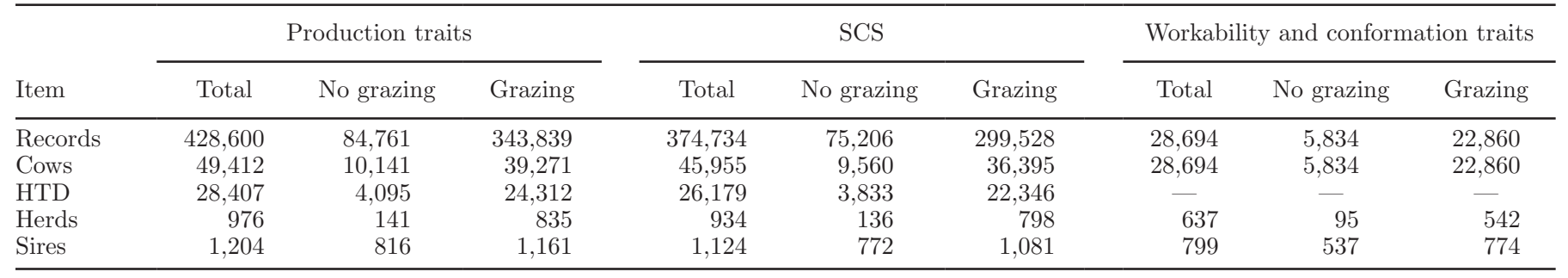


Table 2. Phenotypic means and SD for milk, fat, protein, SCS, workability and conformation traits for the total data set, without selecting on farm type (total) and in farms with and without grazing

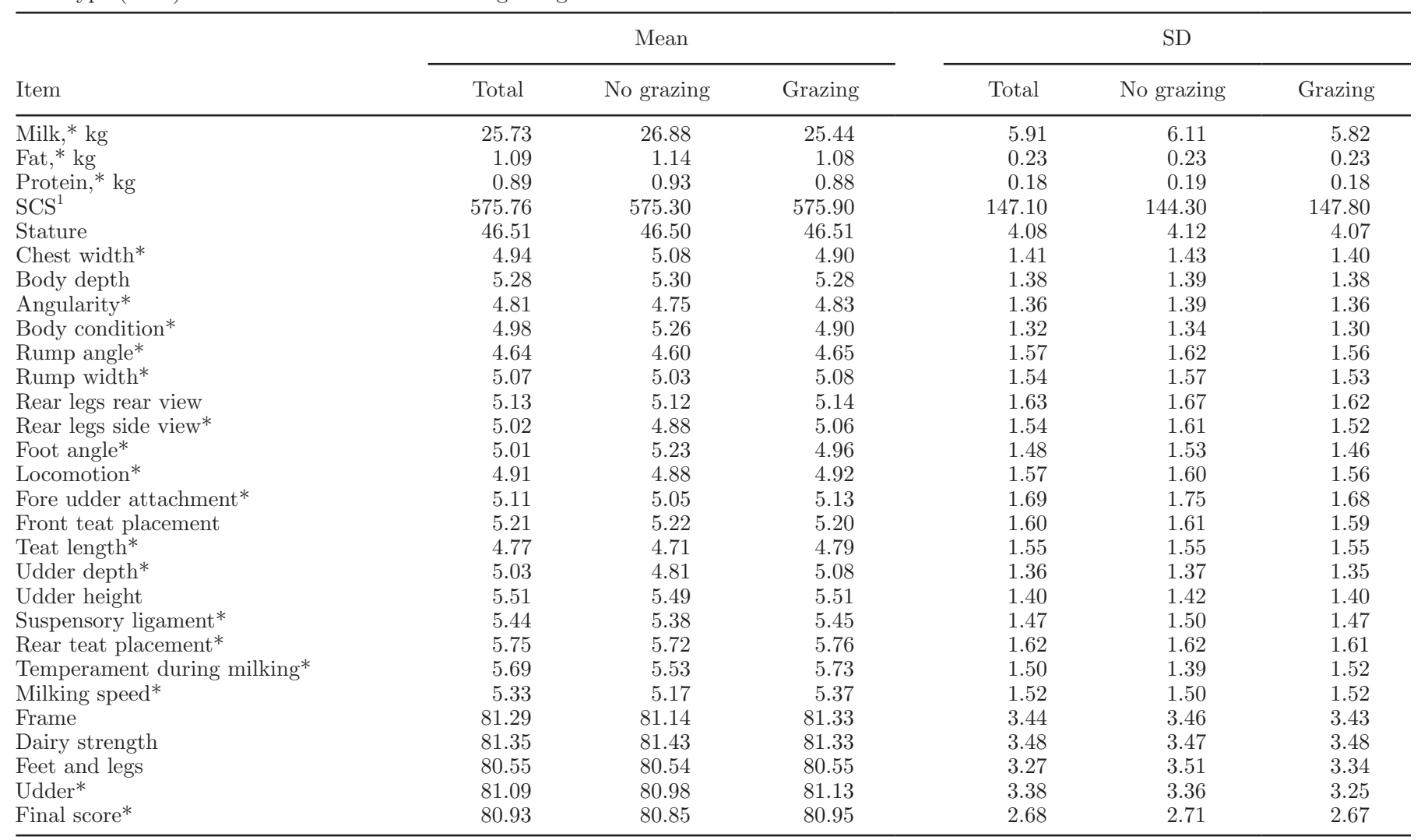

${ }^{1} \mathrm{SCS}=100 \times\left[\log _{2}(\mathrm{SCC})\right]$.

*Significant difference between means on farms with and without grazing $(P<0.05)$.

components, heritabilities and genetic correlations were calculated. The heritability, repeatability for production traits and SCS, and the genetic correlations were calculated by

$$
\begin{gathered}
\mathrm{h}^{2}=\frac{4 \times \sigma_{s}^{2}}{\sigma_{s}^{2}+\sigma_{p e}^{2}+\sigma_{e}^{2}}, \\
\mathrm{r}_{p}=\frac{\sigma_{s}^{2}+\sigma_{p e}^{2}}{\sigma_{s}^{2}+\sigma_{p e}^{2}+\sigma_{e}^{2}}, \\
\mathrm{r}_{g}=\frac{\sigma_{s, n g}}{\sigma_{s, n} \times \sigma_{s, g}},
\end{gathered}
$$

where $\mathrm{h}^{2}$ is the heritability, $\sigma_{s}^{2}$ is the sire variance, $\sigma_{e}^{2}$ is the residual variance, $\mathrm{r}_{p}$ is the repeatability, $\sigma_{p e}^{2}$ is the permanent environment effect variance, $\mathrm{r}_{g}$ is the genetic correlation, $\sigma_{s, n g}$ is the covariance between no grazing and grazing farms, $\sigma_{s, n}$ is the square root of the sire variance in the no grazing farm type, and $\sigma_{s, q}$ is the square root of the sire variance in the grazing farm type. Significant differences between phenotypic means, heritabilities, and repeatabilities were calculated by a $t$-test for 2 samples with unequal variances $(\alpha=0.05)$. A genetic correlation significantly different from unity was an indication for $\mathrm{G} \times \mathrm{E}$ when the genetic correlation was more than 1.96 standard errors from the mean.

\section{RESULTS}

The phenotypic means and standard deviations for milk, fat and protein yield, SCS, workability traits, and conformation traits for the 2 farm types are provided in Table 2 . Table 2 shows that daily milk yield $(+1.44 \mathrm{~kg})$, fat yield $(+0.06 \mathrm{~kg})$, and protein yield $(+0.05 \mathrm{~kg})$ were slightly higher in farms without grazing than in farms with grazing $(P<0.05)$. These differences were significant $(P<0.05)$. The majority of conformation traits 
Table 3. Heritability, repeatability, and genetic correlations for farms with grazing and without grazing for milk, fat, protein, and SCS (SE in parentheses)

\begin{tabular}{|c|c|c|c|c|c|}
\hline \multirow[b]{2}{*}{ Item } & \multicolumn{2}{|c|}{ Heritability } & \multicolumn{2}{|c|}{ Repeatability } & \multirow[b]{2}{*}{ Genetic correlation } \\
\hline & No grazing & Grazing & No grazing & Grazing & \\
\hline Milk & $0.24(0.027)$ & $0.27(0.023)$ & $0.68(0.004)$ & $0.57(0.007)^{*}$ & $0.99(0.013)$ \\
\hline Fat & $0.18(0.022)$ & $0.19(0.018)$ & $0.55(0.005)$ & $0.47(0.006)^{*}$ & $0.98(0.018)$ \\
\hline Protein & $0.18(0.024)$ & $0.20(0.019)$ & $0.60(0.005)$ & $0.51(0.007)^{*}$ & $0.97(0.024)$ \\
\hline $\mathrm{SCS}^{1}$ & $0.08(0.014)$ & $0.08(0.011)$ & $0.55(0.005)$ & $0.55(0.007)$ & $1.03(0.008)$ \\
\hline
\end{tabular}

${ }^{1} \mathrm{SCS}=100 \times\left[\log _{2}(\mathrm{SCC})\right]$

*Significant difference between repeatability on farms with and without grazing $(P<0.05)$.

had significantly different means between environments $(P<0.05)$; however, phenotypic differences were small.

In Table 3, the heritabilities, repeatabilities, and genetic correlations are presented for the production traits and SCS. The heritabilities were slightly higher in the farms with grazing, but not significantly different $(P>0.05)$. For the repeatability, lower repeatabilities were estimated in farms with grazing for milk yield, fat yield, and protein yield $(P<0.05)$. The heritability and repeatability for SCS were the same in both farm types. Genetic correlations between grazing and without grazing were between 0.97 and 1.00 , indicating no reranking of sires due to $\mathrm{G} \times \mathrm{E}$ for production traits.
The estimated heritabilities and genetic correlations for the workability traits and conformation traits are presented in Table 4. Heritabilities differed between environments for all the traits. The difference in heritability was significant only for feet and legs with a higher heritability in the farms without grazing compared with farms with grazing. Genetic correlations were between 0.93 and 1.00 with most estimates between 0.96 and 1.00. Genetic correlations lower than 0.96 were found for feet and legs (0.93), foot angle (0.95), and rear teat placement (0.95). The high genetic correlations indicate hardly any $\mathrm{G} \times \mathrm{E}$ between grazing and no grazing.

Table 4. Heritability and genetic correlation for farms with grazing and farms without grazing for 2 workability traits (temperament during milking and milking speed) and 23 conformation traits (SE in parentheses)

\begin{tabular}{lccc}
\hline & \multicolumn{2}{c}{ Heritability } & \\
\cline { 2 - 3 } Item & No grazing & Grazing & Genetic correlation \\
\hline Stature & $0.46(0.054)$ & $0.51(0.044)$ & $0.998(0.020)$ \\
Chest width & $0.27(0.041)$ & $0.26(0.031)$ & $0.999(0.018)$ \\
Body depth & $0.29(0.045)$ & $0.31(0.035)$ & $0.994(0.024)$ \\
Angularity & $0.09(0.025)$ & $0.06(0.015)$ & $0.963(0.075)$ \\
Body condition & $0.36(0.049)$ & $0.32(0.034)$ & $0.979(0.023)$ \\
Rump angle & $0.30(0.044)$ & $0.25(0.031)$ & $0.992(0.020)$ \\
Rump width & $0.31(0.045)$ & $0.36(0.037)$ & $0.999(0.016)$ \\
Rear legs rear view & $0.14(0.035)$ & $0.11(0.019)$ & $0.969(0.045)$ \\
Rear legs side view & $0.19(0.036)$ & $0.20(0.028)$ & $0.995(0.036)$ \\
Foot angle & $0.21(0.041)$ & $0.15(0.023)$ & $0.954(0.036)$ \\
Locomotion & $0.14(0.023)$ & $0.13(0.021)$ & $0.986(0.040)$ \\
Fore udder attachment & $0.18(0.033)$ & $0.19(0.026)$ & $0.997(0.029)$ \\
Front teat placement & $0.35(0.046)$ & $0.37(0.037)$ & $0.998(0.015)$ \\
Teat length & $0.42(0.054)$ & $0.44(0.041)$ & $0.963(0.023)$ \\
Udder depth & $0.36(0.050)$ & $0.31(0.034)$ & $0.995(0.018)$ \\
Udder height & $0.21(0.036)$ & $0.24(0.029)$ & $0.995(0.028)$ \\
Suspensory ligament & $0.18(0.034)$ & $0.18(0.025)$ & $0.959(0.042)$ \\
Rear teat placement & $0.24(0.039)$ & $0.28(0.033)$ & $0.954(0.038)$ \\
Temperament during milking & $0.07(0.025)$ & $0.11(0.019)$ & $0.989(0.087)$ \\
Milking speed & $0.21(0.040)$ & $0.22(0.030)$ & $0.996(0.036)$ \\
Frame & $0.18(0.034)$ & $0.21(0.029)$ & $0.981(0.034)$ \\
Dairy strength & $0.12(0.029)$ & $0.11(0.020)$ & $0.959(0.062)$ \\
Feet and legs* & $0.18(0.037)$ & $0.13(0.022)$ & $0.933(0.055)$ \\
Udder & $0.20(0.036)$ & $0.12(0.027)$ & $0.999(0.034)$ \\
Final score & $0.18(0.037)$ & $0.16(0.025)$ & $0.955(0.053)$ \\
\hline S & & & \\
\hline
\end{tabular}

*Significant difference between heritability on farms with and without grazing $(P<0.05)$. 


\section{DISCUSSION}

The aims of this study were to investigate the existence of genotype by environment interaction between farms with or without grazing for production traits, SCS, workability traits, and conformation traits in Dutch Holstein-Friesian cows. The results showed that genetic correlations between traits were slightly different from unity, but none of the genetic correlations significantly deviated from 1.00 and reranking of sires due to $\mathrm{G} \times \mathrm{E}$ was almost absent.

We observed phenotypic differences between farms with grazing and farms without grazing for milk, fat, protein, and 17 conformation traits $(P<0.05)$. Repeatabilities for milk, fat, and protein were significantly different in the environments $(P<0.05)$. The genetic correlations ranged between 0.93 and 1.00 for production traits and conformation traits, indicating no significant $\mathrm{G} \times \mathrm{E}$ between farms with or without grazing. The genetic correlations being close to unity imply that the traits on farms with grazing and farms without grazing can be considered as the same trait. An explanation for the absence of $\mathrm{G} \times \mathrm{E}$ for grazing systems in the Netherlands is that cows in the grazing system only spent time grazing during the grazing season. At farms with grazing, cows were grazing on average $10.9 \mathrm{~h} / \mathrm{d}$ and $161.1 \mathrm{~d} / \mathrm{yr}$. This is in correspondence with the average number of days grazing for cows in the Netherlands (Reijs et al., 2013). Most farms practice additional feeding when grass intake is low, indicating that diets on farms with and without grazing are very similar. Furthermore, cows in the grazing farm type are spending half a year in confinement, and differences between environments averaged over the year are smaller than in the grazing season.

The cows in the data sets were assumed to be grazing during the grazing season, starting in May and ending at the end of October. With that information, 4 different environments can be distinguished: without grazing-summer, without grazing-winter, grazing-summer, grazing-winter. The differences between the environments without grazing-summer and grazing-summer are expected to be larger because the observations on the cows on grazing farms will be influenced by the grazing season and not being averaged over grazing in summer and confinement in winter. With larger differences in environments, $\mathrm{G} \times \mathrm{E}$ might be found between no grazing-summer and grazing-summer. The practical relevance of knowledge about $\mathrm{G} \times \mathrm{E}$ between no grazing-summer and grazing-summer is limited, because the aim is to select bulls and cows that perform well in both farm systems for the whole year.
Because environments may differ only in the grazing period of the year, differences in environment year round are very small, and therefore it is not surprising that $\mathrm{G} \times \mathrm{E}$ is absent between farms with and without grazing. On the other hand, these farms may not differ only in grazing system but also in other farm characteristics. For instance, farms with grazing were on average smaller (average herd size $=84$ cows per year) than farms without grazing (average herd size $=125$ cows per year). Furthermore, differences were found in proportions of farms with and without grazing per province (12 provinces). The provinces Flevoland (62\%), Noord-Brabant (29\%), and Zeeland (25\%) had the highest proportions of farms without grazing, whereas the provinces Utrecht (97\%), Zuid-Holland (97\%), and Noord-Holland (93\%) had the highest proportions of farms with grazing. These differences in herd size and region would further differentiate the environments of the 2 groups of farms. Therefore, the expected $\mathrm{G} \times \mathrm{E}$ between these 2 sets of farms may be larger rather than what can be contributed by only the grazing system, but no $\mathrm{G} \times \mathrm{E}$ was found in this study, indicating that the environments were still very similar even though farms differed not only in grazing system, but also in herd size and region.

In previous studies in Canada and the United States investigating $\mathrm{G} \times \mathrm{E}$ between grazing and confinement systems, small $\mathrm{G} \times \mathrm{E}$ effects were found. Genetic correlations and standard errors estimated by Boettcher et al. (2003) for cows in Canada were 0.93 (0.04) for milk, 0.88 (0.04) for fat, and $0.94(0.04)$ for protein. The estimates by Kearney et al. (2004a,b) for US Holsteins were 0.89 (0.03), 0.88 (0.06), and 0.91 (0.03) for mean mature equivalent milk yield, mean mature equivalent fat yield, and mean mature equivalent protein yield, respectively, indicating more $\mathrm{G} \times \mathrm{E}$ than was found in our study. However, the Canadian and US herds that were selected in both studies for the farms with grazing consumed their forage at least 6 mo of the year from pasture. It is not known if the Canadian and US herds received additional feeding during the grazing season, but it may be assumed that differences between grazing and no grazing management on farms are larger than in the Netherlands.

On the farms with grazing, repeatabilities for the production traits were lower and were most likely caused due to the grazing season. Cows in this farm type have a less continuous diet compared with cows that are in confinement year-round. During the grazing season, a large part of the diet consists of DM from outdoor grazing, for which the quality can vary. It was shown that seasonal changes in diet can result in changes of 
milk composition of Dutch dairy cattle (Heck et al., 2009). The estimated heritabilities in this study for milk (no grazing and grazing), fat, protein, and SCS were 0.24 and $0.27,0.18$ and $0.19,0.18$ and 0.20 , and 0.08 and 0.08 , respectively. These estimates were lower than the estimates by CRV, with 0.49 for kilograms of milk, 0.52 for kilograms of fat, 0.41 for kilograms of protein, and 0.25 for SCS (CRV, 2014). The differences in heritability estimates are likely a reflection of using fixed test-day sire model, whereas CRV uses a random regression test-day animal model. Mulder et al. (2004) also used a fixed test-day sire model to estimate heritabilities for production traits and SCS in farms with automatic milking systems and conventional milking systems and found similar heritabilities as in this study: 0.24 and $0.26,0.16$ and $0.20,0.19$ and 0.19 , and 0.05 and 0.06 for milk yield (farms with automatic milking systems and farms with conventional milking systems), fat yield, protein yield, and SCS, respectively. Regarding the conformation and workability traits, all traits had heritabilities that were comparable to the heritabilities used by CRV for breeding value estimation (CRV, 2013).

The remaining question is whether any changes in breeding value estimation or breeding scheme design are necessary. For breeding value estimation, no separate genetic evaluation is needed because we found genetic correlations to be higher than 0.93 for all traits and mostly very close to unity. Potential heterogeneity of variances between both farm types is accounted for in the genetic evaluation system of CRV (Meuwissen et al., 1996). With respect to the breeding scheme, Mulder et al. (2006) concluded that with a genetic correlation higher than 0.61 between 2 environments, the highest average genetic gain was achieved with a single breeding program with progeny-testing all bulls in both environments. Genomic selection may increase this break-even genetic correlation (Mulder, 2007), but given the extremely high correlations between both environments, it is expected that a single breeding scheme is optimal, also in the era of genomic selection.

\section{CONCLUSIONS}

No evidence was found for genotype by environment interaction between Dutch farms with grazing and Dutch farms without grazing for production traits, SCS, workability traits, and conformation traits. Genetic correlations across environments were all well above 0.90. Due to the very high genetic correlations, the EBV of sires with daughters in one environment will be equally well predictive for offspring in the other environment, and efficiency of genetic improvement programs will not be reduced. Thus selection of sires can be carried out in either environment, and therefore no changes in breeding value estimation or breeding scheme are necessary.

\section{ACKNOWLEDGMENTS}

The authors thank CRV BV (Arnhem, the Netherlands) for providing the data.

\section{REFERENCES}

Boettcher, P. J., J. Fatehi, and M. M. Schutz. 2003. Genotype $\times$ environment interactions in conventional versus pasture-based dairies in Canada. J. Dairy Sci. 86:383-389.

Calus, M. P. L., A. F. Groen, and G. de Jong. 2002. Genotype $\times$ environment interaction for protein yield in Dutch dairy cattle as quantified by different models. J. Dairy Sci. 85:3115-3123.

CBS. 2014. Weidegang van melkvee; weidegebied. Accessed Dec. 12 2014. http://www.cbs.nl.

Cienfuegos-Rivas, E. G., P. A. Oltenacu, R. W. Blake, S. J. Schwager, H. Castillo-Juarez, and F. J. Ruiz. 1999. Interaction between milk yield of Holstein cows in Mexico and the United States. J. Dairy Sci. 82:2218-2223.

Coster, A. 2012. pedigree: Pedigree functions. R package version 1.4 http: / CRAN.R-project.org/package=pedigree.

CRV. 2013. Subject: E-8 Fokwaardeschatting exterieurkenmerken. Accessed Dec. 12, 2014. http://www.crv4all.nl.

CRV. 2014. Subject: E-7 Fokwaardeschatting melkproductiekenmerken met testdagmodel. Accessed Oct. 1, 2014. http://ww.crv4all.nl.

Falconer, D. S. 1952. The problem of environment and selection. Am. Nat. 86:293-298.

Falconer, D. S. 1989. Introduction to Quantitative Genetics. 3rd ed Longman Group, Essex, UK.

Gilmour, A. R., B. J. Gogel, B. R. Cullis, and R. Thompson. 2009 ASReml User Guide release 3.0. VSN International Ltd., Hemel Hempstead, UK

Hammami, H., B. Rekik, and N. Gengler. 2009. Genotype by environment interaction in dairy cattle. Biotechnol. Agron. Soc. 13:155164.

Haskell, M. J., L. J. Rennie, V. A. Bowell, M. J. Bell, and A. B. Lawrence. 2006. Housing system, milk production, and zero-grazing effects on lameness and leg injury in dairy cows. J. Dairy Sci. 89:4259-4266.

Heck, J. M. L., H. J. F. van Valenberg, J. Dijkstra, and A. C. M. van Hooijdonk. 2009. Seasonal variation in the Dutch bovine raw milk composition. J. Dairy Sci. 92:4745-4755.

Kearney, J. F., M. M. Schutz, and P. J. Boettcher. 2004a. Genotype $\times$ environment interaction for grazing vs. confinement. II. Health and reproduction traits. J. Dairy Sci. 87:510-516.

Kearney, J. F., M. M. Schutz, P. J. Boettcher, and K. A. Weigel 2004b. Genotype $\times$ environment interaction for grazing versus confinement. I. Production traits. J. Dairy Sci. 87:501-509.

Lynch, M., and B. Walsh. 1998. Genetics and Analysis of Quantitative Traits. Sinauer Associates, Inc. Publishers, Sunderland, MA.

Meuwissen, T. H. E., G. de Jong, and B. Engel. 1996. Joint estimation of breeding values and heterogeneous variances of large data files. J. Dairy Sci. 79:310-316.

Mulder, H. A. 2007. Methods to optimize livestock breeding programs with genotype by environment interaction and genetic heterogeneity of environmental variance. PhD thesis. Animal Breeding and Genetics group, Wageningen University, Wageningen, the Netherlands.

Mulder, H. A., and P. Bijma. 2005. Effects of genotype by environment interaction on genetic gain in breeding programs. J. Anim. Sci. 83:49-61. 
Mulder, H. A., A. F. Groen, G. De Jong, and P. Bijma. 2004. Genotype $\times$ environment interaction for yield and somatic cell score with automatic and conventional milking systems. J. Dairy Sci. $87: 1487-1495$

Mulder, H. A., R. F. Veerkamp, B. J. Ducro, J. A. M. Van Arendonk, and P. Bijma. 2006. Optimization of dairy cattle breeding programs for different environments with genotype by environment interaction. J. Dairy Sci. 89:1740-1752.

Onyiro, O. M., and S. Brotherstone. 2008. Genetic analysis of locomotion and associated conformation traits of Holstein-Friesian dairy cows managed in different housing systems. J. Dairy Sci. 91:322-328.

R Core Team. 2014. R: A language and environment for statistical computing. R Foundation for Statistical Computing, Vienna, Austria. http://www.R-project.org.
Reijs, J. W., C. H. G. Daatselaar, J. F. M. Helming, J. Jager, and A. C. G. Beldman. 2013. Grazing dairy cows in North-West Europe: Economic farm performance and future developments with emphasis on the Dutch situation. LEI Report 2013-001. LEI Wageningen UR, The Hague.

Washburn, S. P., S. L. White, J. T. Green, and G. A. Benson. 2002. Reproduction, mastitis, and body condition of seasonally calved Holstein and Jersey cows in confinement or pasture systems. J. Dairy Sci. 85:105-111.

Wilmink, J. B. M. 1987. Adjustment of test-day milk, fat and protein yield for age, season and stage of lactation. Livest. Prod. Sci. 16:335-348. 